\title{
From Boom to Bust - Oil Exporting Countries over the Cycle 1970-84
}

\author{
Alan Gelb
}

\section{Introduction}

What policies do oil exporting countries' governments follow when faced with vast unexpected windfall gains? What are the consequences for the non-oil economies of such countries and what do they suggest have been the main shortcomings of policy? This article reviews the use made of windfall gains by a sample of developing oil exporters over the period 1974-81, and assesses the effects of their respective choices through 1984. By then the impact of the "oil slump' was becoming apparent so that both the upswing and the downside of oil cycles can be considered, at least to some extent.

If historical, political and institutional constraints are assumed away, windfall gains represent Ricardian rent which is uncommitted to any particular group or use. They may therefore be allocated 'optimally', as defined by some national or social welfare function, both over time and across uses. Consequently they are at least as valuable as any other income stream, and possibly more so; they simply enlarge the sphere of national choice. Although some model-based analyses of oil exporters start from this perspective, experience over the past 15 years has been far more complex. This is mainly because of three factors.

First, the behaviour of world oil markets has been very poorly predicted [Gately 1984]. So have been the historically large swings in exchange rates, nominal and real interest rates and OECD levels of economic activity in the turbulent global environment since

1 Development Research Department, World Bank. The World Bank does not accept responsibility for the views expressed herein which are those of the author(s) and should not be at tributed to the World Bank or to its affiliated organisations. The findings, interpretations, and conclusions are the results of research supported by the Bank; they do not necessarily represent official policy of the Bank. The designations employed, the presentation of material, and any maps used in this document are solely for the convenience of the reader and do not imply the expression of any opinion whatsoever on the part of the World Bank or its affiliates concerning the legal status of any country, territory, city, area, or of its authorities, or concerning the delimitation of its boundaries, or national affiliation.
1972. The range of uncertainty faced by decisionmakers at macro and micro levels therefore widened at the same time as exporters began to receive the windfalls. Because economies do not respond symmetrically to excess demand and supply (with the latter being more costly because of unemployment) excessively optimistic predictions of future levels of oil income tend to be more costly than overly conservative predictions.

Second, government is in its own right a pressure group, whose interests may diverge from any reasonable 'social' welfare function. Indeed, in most countries government embodies competing groups, each with its own agencies and interests, so that decisions may not be consistent either across uses or over time.

Third, despite an increasingly influential view against a major public role in the development process, there is still no consensus on the best way to 'sow the oil' to establish a viable non-oil economy and to accelerate non-oil growth - a major goal of most exporter governments. It is far easier to point to the failures of activist policies than to advocate specific measures of this kind, yet some active developmental role is almost forced upon oil exporting governments because they dispose of much, possibly most, of their country's investible surplus.

For all these reasons, the ideologies, institutions and priorities of the pre-windfall period up to 1973 were to have a major influence on how extra oil revenues were used after that date. In practice, the windfalls did not represent 'uncommitted' income, as they did in theory. Their practical range of uses in any particular country was therefore circumscribed. It is not even clear that taking into account political constraints, they simply widened the choice set; some options politically acceptable under budgetary pressure can be unacceptable when resources are unimaginably abundant.

IDS Bulletin, 1986, vol 17 no 4, Institute of Development Studies, Sussex 
The Use of Windfall Gains: 1974-81

(Base period 1970-72, percentages)

1974-78

\begin{tabular}{|c|c|c|c|c|c|c|c|}
\hline & Algeria & Ecuador & Indonesia & Nigeria & $\begin{array}{l}\text { Trinidad \& } \\
\text { Tobago }\end{array}$ & Venezuela & $\stackrel{1}{\text { Average }}$ \\
\hline $\begin{array}{l}\text { Windfall/non-mining } \\
\text { GDP }\end{array}$ & 27 & 17 & 16 & 23 & 39 & 11 & 22 \\
\hline $\begin{array}{l}\text { Use: } \\
\text { Reducing Trade Deficit } \\
\text { Private Consumption } \\
\text { Public Consumption } \\
\text { Private Investment } \\
\text { Public Investment }\end{array}$ & $\begin{array}{r}-16 \\
13 \\
5 \\
97\end{array}$ & $\begin{array}{l}21 \\
-5 \\
33 \\
23 \\
29\end{array}$ & $\begin{array}{r}22 \\
13 \\
15 \\
-11 \\
50 \\
\\
\mathbf{1 9 7 9 - 8 1}\end{array}$ & $\begin{array}{r}12 \\
13 \\
18 \\
-29 \\
86\end{array}$ & $\begin{array}{l}70 \\
18 \\
-7 \\
19\end{array}$ & $\begin{array}{l}-9 \\
18 \\
15 \\
31 \\
45\end{array}$ & $\begin{array}{r}25 \\
10 \\
14 \\
3 \\
53\end{array}$ \\
\hline $\begin{array}{l}\text { Windfall/non-mining } \\
\text { GDP }\end{array}$ & 29.7 & 22.1 & 22.7 & 21.9 & 34.7 & 8.7 & 23 \\
\hline $\begin{array}{l}\text { Use: } \\
\text { Reducing Trade Deficit } \\
\text { Private Consumption } \\
\text { Public Consumption } \\
\text { Private Investment }\end{array}$ & $\begin{array}{l}30 \\
15 \\
11 \\
43\end{array}$ & $\begin{array}{r}21 \\
5 \\
28 \\
47\end{array}$ & $\begin{array}{r}42 \\
5 \\
16 \\
36\end{array}$ & $\begin{array}{r}0 \\
19 \\
26 \\
55\end{array}$ & $\begin{array}{l}48 \\
25 \\
-27\end{array}$ & $\begin{array}{r}13 \\
108 \\
8 \\
-29\end{array}$ & $\begin{array}{l}30 \\
18 \\
17 \\
36\end{array}$ \\
\hline
\end{tabular}

${ }^{1}$ Unweighted mean. Consumption in Trinidad \& Tobago is split in proportion to split for other countries.

These points have important implications for the 'social value' of windfalls. If more resources do not expand the choice set their value is no longer obviously positive, even if they are perfectly foreseen. There is also of course no presumption that an exporter will fare better with windfalls in a stochastic environment relative to a situation of $n o$ windfalls and a relatively certain environment, since the costs of prediction errors can outweigh the windfall benefits.

\section{The Windfalls and their Use: 1974-81}

Gelb (1986) developed a method to measure the windfalls and account for their uses through decomposing the national accounts; the main results are summarised in Table 1.

For a sample of six non-surplus developing countries - Algeria, Ecuador, Indonesia, Nigeria, Trinidad \& Tobago and Venezuela - the windfalls over 1974-78 from the quadrupling of oil prices averaged the equivalent of 22 per cent of non-mining GDP. ${ }^{2}$ Over 1979-81 they averaged 23 per cent from the redoubling of oil prices. About one quarter was used to reduce trade and current account deficits from unsustainable levels; in the pre-windfall 'base' period 1970-72 deficits had averaged 5.1 per cent of non-mining GDP for the set of countries. Around one quarter was consumed, half by government and half by the private sector. The rest, almost one half, was invested domestically, but the extra investment was entirely by government and public enterprises.

Although deficits were reduced, none of the windfall was saved abroad between 1974 and 1981. Surpluses in 1974-75 and in 1980 offset deficits in 1978 and 1981 which emerged as oil revenues slumped and expenditures were not rapidly curtailed. Although current accounts plus direct investment totalled only

${ }^{2}$ All estimates are based on a breakdown of producer economies into mining and non-mining, rather than oil and non-oil, components. All windfalls and their uses are measured relative to the base period' 1970-72. 
$-\$ 1.9$ bn between 1974 and 1981 there was a rise in net recorded foreign debt of $\$ 35.2$ bn because of capital outflows. ${ }^{3}$

Essentially then, the windfalls funded some international diversification of portfolios, some consumption and much domestic public investment. On average, about two thirds of this was directed towards sectors conventionally considered as non-traded roads, ports, telecommunications, utilities and other physical infrastructure and social investments in health and education - and one third to exporting and import-substituting sectors, notably large-scale resource-based industrial projects - steel, aluminium, methanol, urea, ammonia, piped gas, LNG and refining.

The consequences of this pattern of absorption are analysed below. Meanwhile, it is important to stress the options which were not extensively adopted. There was little saving abroad except in Trinidad \& Tobago. Windfalls were not redistributed to the private sector to any great extent, either directly or by cutting non-oil taxes, although subsidies of various kinds rose to a significant share of budgetary spending, especially in the richer exporters, Trinidad \& Tobago and Venezuela [Auty and Gelb 1984, Bourguignon 1985]. A further implicit subsidy to domestic energy users resulted from widespread reluctance to raise prices of oil derivatives to world levels. In several countries government collected little or no revenue from oil produced for domestic use, and subsidies rose to the equivalent of about five per cent of GDP before shrinking fiscal revenues forced sharp increases in energy prices in the early 1980s. As a result, consumer prices rose less rapidly than investment prices or nonmining output deflators, especially in the richer countries in the sample, and real consumption levels rose far more than indicated by the increases in value shares relative to non-mining GDP, in Table 1.

Except in Indonesia where rural rehabilitation and the need to raise output had been policy goals since the start of the Suharto government, oil revenues were not directed towards smallholder agriculture. In certain countries agricultural spending did rise, but most went for large public projects [for discussions of Nigeria and Iran see Bienen 1983, Katouzian 1978 and Jazayeri in this Bulletin] or as subsidies to failing state enterprises [especially to sugar in Trinidad \& Tobago; Auty and Gelb 1984]. With the exception of the larger public projects mentioned above, there were no major attempts to strengthen export-oriented manufacturing.

\footnotetext{
${ }^{3}$ The change in net recorded debt is defined as the change in medium and long term debt less reserves plus the change in short term debt over 1979-81. Certain capital exports such as international assets of domestic oil companies are official though not counted as reserves, but much capital outflow was unofficial.
}

The sector typically remained weak, protected and oriented towards domestic markets which grew rapidly while public spending rose. Direct foreign investment was disappointing. In some countries it was discouraged by indigenisation policies which aimed to expand the sphere of national control another common goal of oil exporting governments.

Finally, the windfalls were not used to effect major improvements in administration and regulation, though they offered a breathing space to carry out such reforms. For example, a slight slackening of nonoil tax effort in certain countries was not an irrational response to rising oil revenues. But the countries failed to take advantage of low revenue needs to put into place tax systems capable of raising domestic revenues more efficiently should oil revenues fall. One country, Indonesia, did however implement a major tax reform in 1984.

This broad summary should not obscure the very considerable differences between countries. As shown in Table 1 there were considerable variations in the broad patterns of response, and there were considerable differences in investment emphasis. Algeria followed an exceptionally intensive heavy industrial strategy and borrowed abroad against future export revenue to help finance it; by 1977 its investment programmes ( 90 per cent public) had reached the remarkable level of 73 per cent of non-mining GDP. Ecuador emphasised infrastructure, electrification and education. Indonesia followed a relatively balanced strategy with a unique emphasis on rural reconstruction, irrigation and smallholder rice intensification. Nigeria first emphasised road-building and education programmes, and later added steel plants and a new Federal capital city. Trinidad \& Tobago sought to overcome an infrastructural backlog which had developed in the late 1960s and also initiated a diverse set of gas-based industrial projects while saving much of its windfall abroad between 1974 and 1981. Venezuelan public investments emphasised especially the metals industries, steel, aluminium and their associated infrastructural needs. The country also experienced large capital outflows.

These differences reflected, to a great extent, preshock differences in institutions and a strong element of inertia. The suddenness of the windfalls coupled with a desire to absorb them rapidly led the volume of public spending to change far more rapidly than political systems or institutions. Large increases in revenue therefore tended to be channelled into a relatively narrow range of uses where rapid disbursement was possible. But by the same token, oil revenues were generally not applied in ways which required politically difficult adjustments or lengthy institutional development. To cite some examples, 

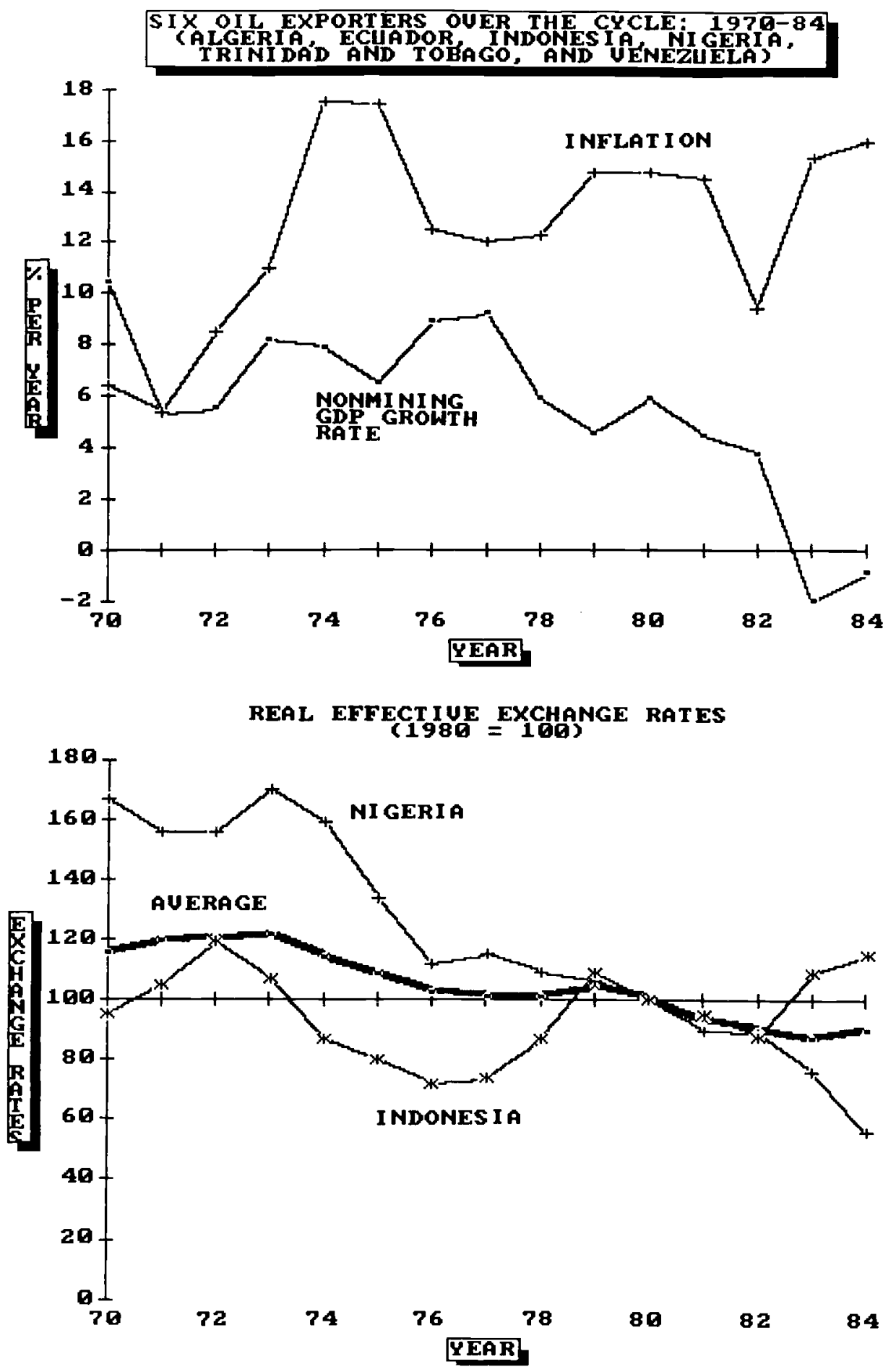
although the windfall offered Ecuador the resources to effect a major land reform with compensation, this objective was set aside in favour of limited 'colonisation' of new lands. Despite the impediment that lack of an effective extension service posed for agricultural growth in Nigeria, oil money did not flow in this direction.

\section{Consequences of the Strategy: 1974-81}

The theory of 'booming sector' economies [Corden and Neary 1982] suggests that increased spending of windfall gains will result in an appreciation of the real exchange rate (an increase in the relative price of nontraded goods), followed by a resource shift away from the non-oil traded sectors and an increase in oil dependence. In the longer run, factor intensity differences or changes in efficiency caused by oil financed investments may offset some of these effects. If extra spending is largely invested, neoclassical growth theory may be used to project the increase in growth, assuming constant quality of capital formation. Output may also respond to the pressure of demand. On the upswing of the cycle the ability to do so depends on the existence of spare capacity. On the downside, the extent to which real output contracts in response to falling demand or to supply shocks (such as those emanating from increased input prices) depends on the extent of real and nominal wage and price rigidities or sluggishness [Kanbur 1984, Gelb 1985].

The experience of the oil exporter sample from 197084 is summarised in Figure 1, which shows growth rates of non-mining GDP, inflation rates and real effective exchange rates. ${ }^{4}$ All graphs show unweighted averages for the six countries and real effective exchange rates are shown separately for Indonesia and Nigeria. Considering the period $1970-81$ for the moment, this may be divided into four phases:

(i) 1970-72: the end of recovery from the domestic shocks of the mid-1960s (in Algeria, Nigeria and Indonesia) which were responsible for an unusual burst of growth. The average non-mining GDP growth rate fell from over 10 per cent in 1970 to 5.3 per cent in 1971 and 1972.

(ii) 1972-77: the upswing of the first boom. Domestic prices rose sharply and real exchange rates appreciated as spending accelerated. Resources were reallocated towards the non-tradeables, especially construction, which grew at 13.9 per cent. This permitted a rise in

\footnotetext{
${ }_{4}$ The real effective exchange rate is defined as the weighted average of trading partners' price levels relative to domestic prices converted at annual average exchange rates. It is used as a proxy for the real exchange rate (defined as relative price of traded and non-traded goods) because the latter is difficult to measure when goods display a continuum of tradeability. The two measures can diverge if trade policy changes.
}

output in 1976 and 1977 and a fall in inflation.

(iii) 1977-79: the downside of the first boom. As oil income and spending slackened after 1977 fiscal policy became less expansive. On the upswing of the boom capacity constraints in the non-traded sectors had limited the speed with which output could respond to increased demand; the result was that real exchange rates appreciated, deflecting demand onto rapidly growing imports. As demand fell, real output and capacity use contracted sharply, but inflation accelerated slightly. This was partly a result of the inflationary momentum which had built up in the boom period. But it also reflected increased domestic financing of public sector deficits which opened up as oil revenues fell below even the moderating spending levels. It was not possible to rapidly reallocate factors from the non-traded sectors, where demand was slackening, to the non-oil tradeables. This period therefore provides the first indication of asymmetric macroeconomic adjustment. By the start of the second boom in 1979 growth was lower and inflation higher than in 1972 and 1973, the start of the first boom.

(iv) 1979-81: the second boom. This was far more abrupt than the first and its impact was smaller. Inflation rates remained almost unchanged as did non-oil growth rates, with a slight acceleration only in 1980.

Over the period 1974-81 the average growth rate of non-mining GDP was 6.7 per cent. This was lower than in 1967-72 (7.3 per cent) but 0.9 per cent greater than the average growth rate of oil importing developing countries over the 1960s. From Figure 1 it is apparent, however, that 1977 marked the end of the high growth phase, despite intensive domestic capital formation which should have ensured continued rapid growth through 1981. There were thus signs of a disappointing supply-side impact from the accelerated public investment programme.

To conclude this brief appraisal of the 1974-81 period, consider the evolution of non-oil exports. These stagnated or fell in all of the countries except Ecuador (where there was modest overall growth and a shift towards processed products) and Indonesia, which maintained a strong export performance over a fairly wide product front. It cannot be claimed that Indonesia's trade regime was liberal; outside the small-scale sector international transactions and investments continued to be intensively regulated. However, Indonesia was far more ready than the other countries to adjust the non-oil exchange rate in response to expected shortages of foreign exchange. The Rupiah was devalued by 50 per cent in November 1978 and floated and devalued again as the second oil boom came to an end. The periods of severe real effective appreciation were limited, as shown in 
Figure 1. Nigeria, to take a contrasting case, responded to shrinking oil revenues by tightening quantitative import controls so that the real effective exchange rate of the Naira appreciated continuously. This seriously reduced the incentive to export, and also increased fiscal pressure on government by reducing the domestic purchasing-power of oil revenues.

\section{The Oil Glut: 1981-84}

The second oil shock had led to a combined current account surplus of $\$ 11.8$ bn for the sample in 1980 and an optimistic world scenario for oil exporters. Most projections were of real increases in world oil prices of the order of three per cent per year. But with weakening energy demand in OECD countries, the dollar value of exports fell by 22 per cent in the sample countries in 1980-82. Imports, propelled by the second burst of public spending, rose by 23 per cent, resulting in a 1982 current deficit of $\$ 20$ bn. Such a deficit could not be financed in following years; contractionary policies were implemented and it was cut to $\$ 7$ bn by 1983. These policies included sharp reductions in public spending (Indonesia cancelled or postponed half of its projected heavy industrial investment programme) and cuts in domestic subsidies, particularly to energy consumption, as countries took steps to raise administered prices. Taking 1981 as the reference point, the period 1982-84 saw an average fall in the contribution of the mining sector equivalent to eight per cent of non-mining GDP and a reduction in foreign financing of one per cent. About three quarters of this loss was reflected in cuts in investment programmes; the remainder was absorbed equally by decreases in public and private consumption relative to non-mining GDP.

The combination of spending cuts, increases in administered prices and, in several cases, increased prices of imported intermediates because of exchange rate adjustments subjected the exporting economies to a combination of demand and supply shocks not dissimilar to those which faced the oil importing countries in the upswing of the cycle. ${ }^{5}$ Non-oil exports could not expand rapidly enough to compensate for their small base. Not unlike the oil importing countries in earlier years, the exporters were propelled into stagflation in 1983 and 1984, with negative growth as shown in Figure 1 and rising unemployment. Ecuador, Nigeria and Venezuela experienced foreign exchange crises on the downside of the second oil shock. Indonesia avoided crises by rapidly adjusting the exchange rate and liberating interest controls. Trinidad and Tobago had ample reserves and Algeria

${ }^{5}$ Had domestic oil prices followed world prices in the exporting countries they would have experienced part of the supply shock in 1974 and 1979 , as did importing countries. a tightly controlled foreign exchange market and growing gas exports.

The effect of this pcriod was to lower still further the average non-oil growth rate of the sample to only 4.7 per cent over 1974-84. This was 1.1 per cent lower than the average growth rate of developing countries in the 1960s. Adverse terms of trade for oil were not responsible; even in 1985 the purchasing power of oil exports was far larger than it had been before 1974 . The main reason was the failure of public investments to have an appreciable supply-side impact, a topic addressed in the following section.

\section{Accounting for Supply Side Failure}

As noted above, about two thirds of public investment in the sample countries was directed towards the nontraded sectors and consisted mostly of physical infrastructure and social spending. Such expenditures had some notable effects. In 1970 the primary enrolment ratio for the sample had averaged 0.79 , well below the corresponding ratio for middle income countries $(0.88)^{6}$; by 1982 the shortfall had been made good and universal primary education was almost achieved. Population per nursing person fell from 3,000 to 1,200 ; infant mortality declined by a third. Nevertheless, investment in the non-traded sectors did not provide an autonomous source of income to supplement falling oil revenues; its supply-side contribution was only 'permissive' of other activities.

Therefore attention focuses on the large scale industrial investments which were a major part of Government's assumption of an entrepreneurial role in all of the sample countries except Ecuador. Such investments: (a) are visible, (b) can absorb large sums rapidly, (c) have a high import content so that there is less pressure on domestic sectors, (d) are a source of patronage (sheltered employment for supporters, kickbacks from contractors), (e) promise loan capital via suppliers" credits, and (f) promise export diversification out of oil without requiring the politically hard choices which go along with restructuring the rest of the manufacturing sector. Therefore they were favoured by producer governments. Many devoted the equivalent of one or two years' total oil exports to such projects; some, like Algeria, devoted more.

Although it has not been possible to make a detailed quantitative assessment of rates of return, overall performance appears to have been very poor. The reasons for this have been studied by Auty (1986); th is section draws heavily on his conclusions.

\footnotetext{
"All averages for the sample are unweighted averages of country ratios.
} 
The most important factor in the poor performance of public industrial investments has been the downturn in world markets for many of their products after 1980. Not only did this result in real product price projections being revised downwards by some 25 per cent, but slow growth or in some cases contraction of world markets led to serious marketing problems for the new plants. This, in turn, resulted in low levels of capacity use, and raised unit costs since the share of variable costs tends to be low in such industries.

Problems of domestic origin frequently compounded those of external origin. Cost and time overruns were commonplace, with the former usually being in the 30-100 per cent range, and the lat ter sometimes several years. Many projects may never be completed. The larger and more complex the project, the greater the probability of serious overruns [Murphy 1983]. Overruns are not peculiar to developing countries the trans-Alaska oil pipeline, for example, came in at $\$ 8$ bn versus a projected cost of $\$ 900 \mathrm{mn}$. Like the large projects, it represented a quantum jump in size and sophistication relative to its local economy. There were few precedents, and many unexpected difficulties.

Hastily planned and built, many plants in the oil countries experienced serious operating problems and excessively high current costs. One steel complex had three times the necessary manpower before start-up. In another plant inexperienced operators caused severe damage and losses to the tune of hundreds of millions of dollars.

The net result has been very poor financial and economic rates of return, with some public manufacturing programmes unable to cover even their wage bills, let alone the costs of other inputs and a return to capital. Many plants have survived only through the imposition of taxes, in the form of import restrictions, on the rest of the economy, a heavy burden on using sectors. Poor public investments have left governments facing a difficult choice - to subsidise directly, to protect and so devolve the cost to other sectors, or to close down and write off their losses.

The involvement of foreign partners has sometimes imrroved operating performance. Foreign partners nave also helped to assure markets. For example, Indonesia's LNG plants, constructed with heavy foreign financial and technical involvement, have benefited from assured markets abroad; Algeria's larger LNG installations, which are wholly stateowned, ran at less than half capacity. Marketing has been a problem for many countries which built plants far in excess of domestic demand. Clearly, this is potentially most serious for small countries; in Trinidad \& Tobago, for example, ISCOTT, the state steel company, had operating costs about 50 per cent above those of efficient US minimills, and antidumping charges were successfully brought when it attempted to export to the vital US market [Auty and Gelb 1984].

The record also reflects adversely on the process by which such investments were selected.

(a) The weight attached to resource availability was far too large relative to capital costs, capacity use and recurrent cost levels. Profits of such plants are typically at least three times as sensitive to product prices or to capacity use as to the charge for the key natural resource.

(b) 'Consensus' and moral hazard in appraisal: Auty (1986) suggests that consulting firms appraising projects may be considered to fall into two types. The first has no apparent financial interest (though others argue that there are few truly independent project appraisers), and therefore has little interest in assessing performance outside a 'range of consensus' which prevails at the time regarding product outlook, energy costs, interest rates, etc. If events turn out to be very different, the firm can justify its assessment with the argument that 'everyone else was wrong too'. Risk is therefore not properly accounted for, and sensitivity analyses performed for such ventures typically do not address the performance of the project under radically different market conditions. This means that they do not consider what the acceptable rate of return needs to be if things evolve as projected to compensate for the probability that there will be a major downturn in markets or large cost overrun.

The second type of appraising firm has a substantial interest (as a supplier) and may be prepared to take a small equity stake. This it can easily cover through sales and fees, however, especially as costs overrun and its st ake shrinks. This introduces a double element of moral hazard. The appraiser-supplier has a strong stake in having the project go forward and little interest in cutting costs once it has started.

(c) Measuring the competition. Appraisals rarely considered the cost structures of current competitors. Because of over-optimistic market growth scenarios they assumed competition with future plants rather than existing ones. In 1974-76 it was argued that future plants would be far more expensive because of rapid inflation in plant costs and negative real interest rates; in 1980-81 (the other spurt of industrial investment) over-optimistic projections of energy prices swamped other considerations.

\section{Conclusion}

A full assessment of the impact of the decade of oil 
windfalls on producers will not be possible for many years. Much infrastructural investment is slow to yield; some resource-based investments, even if poorly timed, may turn out to be profitable should their markets recover. The record so far suggests, however, that the benefits have been far smaller than expected. This has been due partly to the increased uncertainty which accompanied the windfalls, partly to the asymmetry of macroeconomic adjustment and partly to the low quality of much public capital formation. The exporters would almost certainly have benefited from saving a larger share of the windfall abroad and from applying market criteria more thoroughly to screen investments.

Simulations with a multisectoral general equilibrium model suggest that private consumption increases by only about 30 per cent of investment expenditures when the economy is fairly near full capacity [Gelb 1985], via multiplier and real exchange rate effects. Poor public investments are an inefficient way to channel oil income to the private sector. If greater saving abroad is ruled out as politically infeasible, certain countries might fare better by transferring a greater share of their oil income directly to their citizens. Another option might have been to use oil income to encourage non-oil exports. Broad uniform incentives could compensate exporters for the appreciated exchange rate but producers would still need to compete to standards required by world markets. To be effective, this strategy would require a very liberal import policy. As oil revenues fell, devaluations would compensate exporters for the loss of fiscal incentives and encourage import substitution, which would probably be easier than rapidly attempting to develop exports.

\section{References}

Auty, R., 1986, Entry Problems in RBI, World Bank (mimeo), Washington D.C., February

Auty, R. and A. H. Gelb, 1984, The Deployment of Oil Rents in a Small Parliamentary Democracy: the Case of Trinidad and Tobago, World Bank (mimeo), Washington D.C., February

Bienen, H., 1983, 'Oil revenues and policy choices in Nigeria', World Bank Staff Working Papers No 592, Washington D.C.

Bourguignon, F., 1985, Are Oil Windfalls a Blessing or a Curse? The Venezuelan Experience, 1972-84, World Bank (mimeo), Washington D.C.

Corden, W. M. and J. P. Neary, 1982, 'Booming sector and de-industrialisation in a small open economy', Economic Journal 92, December, pp825-48

Gately, D., 1984, 'A ten year retrospective: OPEC and the world oil market', Journal of Economic Literature, Vol. XXII, September, pp 1 100-1114

Gelb, A. H., 1985, 'Are Oil Windfalls a Blessing or a Curse? Policy Exercises with a Model of Indonesia', Discussion Paper No DRD 135, Development Research Department, World Bank, Washington D.C.

-1986, 'A comparative analysis of oil exporting countries', in P. Neary and S. van Wijnbergen (eds.), Natural Resources and the Macroeconomy, CEPR, London

Kanbur, S. M. R., 1984, 'How to analyse commodity price stabilisation? a Review Article', Oxford Economic Papers 36 , pp336-58

Katouzian, M. A., 1978, 'Oil versus agriculture: a case of dual depletion in Iran', Journal of Peasant Studies, vol 5 no 2, April, pp347-69

Murphy, K., 1983, Macroprojects in Developing Countries, Westview Press, Boulder, California 